\title{
Impact of Virtual Workspace Adoption on Organizational Performance in Nigeria Banking Industry
}

\author{
Isokariari, Telema \\ Department of Business Administration, Faculty of Management Sciences, \\ Nile University of Nigeria, Abuja
}

\begin{abstract}
This work examines impact of virtual workspace adoption on organizational performance in Nigeria Banking Industry. The specific objectives of this study include: to determine the extent to which intranet facility affects profitability of Nigeria banks and to ascertain the extent to which extranet facility affects market share of Nigeria banks. The study adopted the survey design. The population of this study consists of staff of 23 Banks in Nigeria. The study employed a census of 399 respondents which was reduced to 381 after questionnaires were distributed and retrieved. The sources of data for this research work were primary and secondary. Questionnaire was adopted as the method of data collection and designed on a five-point likert scale research instrument. Content validity was conducted to test the validity of the instrument and this was achieved with five management experts: three from the academia and two from industry. Data analysis was done using multiple linear regression analysis with Analysis of Variance (ANOVA) with a five percent level of significance. The findings showed that: intranet facility had a significant positive effect on profitability of Nigeria banks and extranet facility significantly affected market share of Nigeria banks. The study recommends that bank technical team and system developers, should ensure that sites and apps are designed with optimum simplicity to ensure ease of use and reduce TAT (turnaround time) while the bank management should encourage customers to adopt online banking by offering incentives like reduced Cost of Transactions (COT).
\end{abstract}

Keywords: Virtual Workspace, Organizational Performance, Intranet Facility, Extranet Facility, profitability, Market share.

DOI: $10.7176 / \mathrm{EJBM} / 13-6-18$

Publication date:March $31^{\text {st }} 2021$

\section{Introduction}

The Nigeria banking industry has witnessed several transformations ranging from the emergence of the internet which is in a bit to increase customer confidence and service delivery. World-wide, internet technology has seen an exponential improvement, this has engendered several opportunities in all aspects of life (Dreck, 2016). The internet has continued to immensely impact on the individual, groups, institutions, businesses, and nations both economically, socially, and culturally. Even now, we continue to see fresh and radical new ideas like e-banking, e-governance, e-learning, e-business etc. The e-banking has proven to be an important addition and key revenue driver to the banking industry since the inception of the 21 st century, and it is also witnessing rapid growth in Nigeria and some other African countries.

The advent of the internet has significantly altered the conventional method of banking. Banking transactions, learning, and training, exchange of goods and services can conveniently be done online or from the comfort of your bedroom. Consequently, the introduction of platforms such as mobile banking; a platform that allows customers carry out banking transactions with mobile phones, internet banking; bank website downloaded on personal computers that allows customers bank from the comfort of their homes and ATM; a housed device that pairs with a chip and pin card technology dispensing cash to customers at the go, has aided the delivery of banking services in an efficient manner that is worthy of applause. This is because, in present day banking system, excellent customer service is the most important competitive tool for sustained business growth (Yaha, 2018).

Similarly, the adoption of virtual workspace and its impact on organizational performance in Nigeria banking system has become more significant to their business operations and subsequently the increase in performance of the banks. Hence, it has facilitated transactions and increase satisfaction (Fajana, Owoyemi \& Gbajumo, 2015). Virtual workspace which is a part of the virtual human resource management can be considered to still at its infancy in the country with a lot of room for research to add to the literature in this area. The adoption of new management tools, skills, and techniques in the running and admisitration of firms are all aimed at running a cost-efficient system. A good virtual workspace is important to attaining a stable and profitable banking system industry in Nigeria in the 21 st century (Lee, 2013).

Finally, Ihenyen, (2015) posited that. given the impact of virtual workspace in organizations; the high level of communication and empathy towards employees, employees' effectiveness, organizational performance, manager-employee collaboration and the impact on Nigeria banking industry, virtual workspace should be taken seriously by all organizations. Therefore, this research work is to examine the impact of virtual workspace adoption on organizational performance in the Nigeria Banking Industry. 


\subsection{Statement of Problem}

It is expected that Information Technology (IT) in the banking industry should promote efficiency and customer satisfaction. This is because the days of high customer commitment are declining hence there is a need to find out what it takes to keep a customer loyal in the electronic world of banking (Hanth, \& Tracy, 2017).

However, virtual workspace systems that do not bring about communication satisfaction amongst employees is not likely to result in job satisfaction or improve performance of the organization notwithstanding the quantum of the information transmitted (Pen, 2019). As regards the distribution of virtual workspace within an organization, it is becoming increasingly complex following globalization. With employees working in different geographical locations, usually across state or even country lines, it increasingly becomes more difficult to communicate and this most likely will lead to high operational costs. Virtual workspace may cause ineffective communications, hence complications (Holt, 2016). This can contribute to misinterpretation or multiple misinterpretations of messages by employees that can cause problems and hinder the running of operations within the organizations.

In the virtual world, collaboration may be somewhat a challenge to attain, more so if employees work from different geographical locations. It should be noted that working virtually together does not equate to collaborating with one another in the real sense. While Virtual workspace may have provided real-time communication amongst employees, it appears to lack that face-to-face interaction which is a critical component in communication. No doubt it offers a range of convenient and efficient meeting options, a key challenge especially in developing countries like Nigeria is the long standing basic infrastructural challenges like poor network and frequent equipment breakdown, these causes disaffection amongst employees and customers alike (Yang, 2015).

\subsection{Research Objectives}

The main objective of the study was to examine the impact of Virtual workspace adoption on organizational Performance in the Nigeria banking industry while the specific objectives were as follows:

iii. To determine the extent to which intranet facility affects Customer retention in Nigeria banks.

iv. To ascertain the extent to which extranet facility affects Market Share in the Nigeria bank.

\subsection{Research Questions}

iii. To what extent does intranet facility affect Customer Retention in Nigeria banks?

iv. To what extent does extranet facility affect Market Share in Nigeria banks?

\subsection{Research Hypotheses}

Based on the research questions, the following research hypotheses were formulated:

H01: There is no significant relationship between intranet facility and Customer retention in Nigeria banks.

H02: There is no significant relationship between extranet facility and Market Share in Nigeria banks.

\section{Literature Review}

2.1 Conceptual Framework

Conceptual Framework of the Study: The study considered concepts relating to the dependent and independent variables as show below.

\section{Conceptual Framework of the Study}

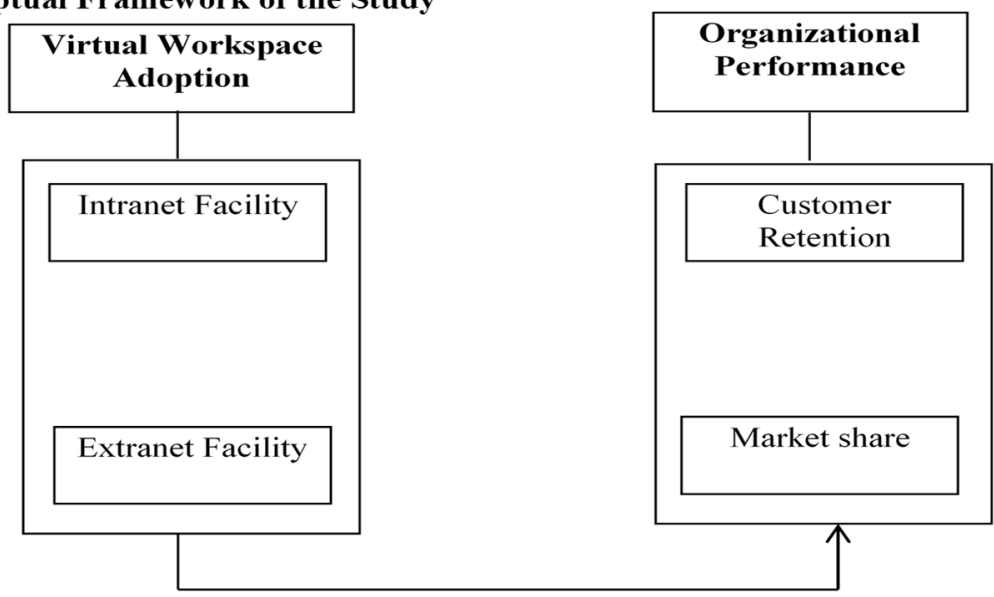

Table 1: Conceptual framework of impact Virtual Workspace on Organizational Performance of Nigeria Banking Industry.

Source: Desk Research, 2020. 


\subsubsection{The Concept of Virtual Workspace Adoption}

Virtual workspace adoption is the acceptance of a firm to employ the use of an internet facility in its operations (Powell, Piccoli \& Ives, 2014). It involves a client or employee computer connecting to a central machine that hosts virtual applications and computers. These virtual machines reside on powerful severe hardware centrally located and are built on top of hypervisor software. End-users typically are able to access the full desktop environment, they also have the capability to store data and applications of remotely (Bell \& Kozlowski, 2002). This also involves the ability to direct, coordinate, control and organize the activities of a team with members in different locations or even time zone and possibly in different organizations. (Wendy, 2019). It rides on the realization that trust is a more limiting factor than people, process and technology compared with face-to-face interactions (Duarte \& Snyder, 2006). Peters and Manz (2017) are of the opinion that Virtual workspace involves the management of work across boundaries of time and space through the utilization of modern computer-driven technologies.

According to Loughran (2005), Virtual workspace adoption is the organization of people from different locations working together towards a common objective with the aid of intranet and extranet facilities linking workstations across time, space, and cultural barriers. A drawback amidst all the advantages is the high-risk nature in terms of data security. To increase the chances of success in the adoption of virtual workspace, organizations should demonstrate commitment to investment in technology, hardware, and staff training. All these must be accompanied by strategy to reduce uncertainty of virtual contacts and activities. Virtual workspaces are mainly used for remote work with high performance and low cost. It enables employees to interact in a collaborative working environment regardless of where they are located (Bavec, 2002).

\subsubsection{Customer Retention}

Customer retention is the actions companies take to get their customers to continue using their services. Surprisingly, it is not a high priority for most businesses (Don Havstrand, 2009). According to Forbes, as recently as 2012 many businesses ranked "driving sales" as their top priority while "building customer loyalty" was the last place. Haward and Upton (2001) say "Customer retention refers to the ability of a company or product to retain its customers over some specified period. High customer retention means customers of the product or business tend to return to, continue to buy or in some other way does not defect to another product or business, or to nonuse entirely". Clearly it is desirable to build a strong customer retention as this improves the lifetime value of customers and ultimately profitability of the company.

\subsubsection{Market share}

A company's market share is its sales figures measured as a percentage of the industry's total revenue (Steven, 2015). Market share represents the percentage of a given industry total sales that is earned by a particular company within that industry over a specified time period. It is the ration of the company's sale over the period to the total sales of the industry over the same period. Increasing market share is one of the most important objectives of business because it serves as a measure of organizational performance (Boundless, 2017.

\subsubsection{Intranet Facility and Organizational Performance}

Intranets are private, secured networks that exists within an organization that are used to share information effectively (Shereen, 2018). According to Axero (2018) "an intranet is a network where employees can create content, communicate, collaborate and get stuff done". The objective of an intranet facility is to assure ease of communication, collaboration and document sharing for employees within an organization in a safe and secure manner (Berry, 2011). It provides a virtual space for employees to work together, which is great for when people are spread out geographically. It optimizes existing business processes to centralize information, reduce complexity and maximize productivity. The effectiveness of virtual employees depends on effective intranet system which foster performance in the organization (Wang, Su \& Yang. 2011).

\subsubsection{Extranet Facility and Organizational Performance}

While Intranet creates collaboration only within an organization in a given geographic location, Extranet creates an avenue for that handshake to happen with the systems outside the geographic location of the organization. It is essentially an extension of intranet. Enabling the organization to share documents, files, and other important information (Holt, 2016). The extranet provides a lot of benefits and has proven to be intrinsic to business operation and hence survival. Organizations that hope to explore the market and maintain security as well as provide access to information across boundaries necessarily need to have a well-grounded extranet facility as part of it key enablers. According to Michelle (2015), employing the use of extranet facilities improves profit leads to increase in profit margins by being more nimble and operationally efficient and increased productivity within the organization, either by means of innovative solutions or through the increased sharing of knowledge through virtual means and it increase in effective communication with clients, associates and even partners. Consequently, increase in time saved, leads to increase in productivity. In the banking sector where time equals cab be said to equal money, every second saved translates to huge gains for them (Cherbakov \& Luba, 2009). Extranets facility provides enablement such as: videoconferencing, audio-conferencing, instant messaging, text messaging, phone calls, conference calls, conference calls, e-mail, wikis, discussion boards, application-specific groupware, or 
shared databases etc. (Holt, 2016).

\subsection{Theoretical Framework}

\section{Dutta and Segev's Theory}

The study is anchored on Dutta and Segev's theory (2001) of Cyber transformation and companion Marketspace model which belong to the E-strategy School of thought about online retailing. They researchers are of the view that organizations should change their business models to take advantage the benefits that exist in the use of the internet as a business channel.

Dutta and Segev's in this study attempted to put deduce from the results of various Critical Success Factor (CSF) studies in E - commerce adoption into an all-encompassing theoretical framework for online business. They also assert that the early nineties (1992) advent of the World Wide Web (WWW), provided several businesses an opportunity for multimedia-based information system which could be used for new market development and provide different and profitable ways of doing business. The online business space (e-commerce) was greeted with great Enthusiasm and resulted in a plethora of start - ups, new ways of doing business and online business models. A whole new vista was opened up for products and services.

\subsection{Empirical Studies}

Mitchell (2015) researched on the correlation between virtual communication and employee engagement. The purpose of the study was to examine the significance of the correlation existing between employee engagement as the dependent variable and the quantity/quality of virtual management communication as the independent variable. 75 virtual workers from $\mathrm{ABC}$ (which is a US based organization) designs was chosen as the population of the study. Volunteer sampling (which is a form of purposive sampling under the non-probability sampling technique) was adopted as the sampling technique. Data analysis was conducted using the statistical package for social sciences (SPSS). The regression analysis showed that there was a statistically significant relationship between the variables, which indicates that the amount of time managers spend on communicating with employees over virtual means and the employees' actual quality of communication affected employees' engagement positively, this also affects organizational performance in the main. He concluded that the goal of the study which was to create a deeper understanding of virtual management and the environment surrounding communication between managers and employees was achieved. Finally, the study recommends that the relationship between employees and employers can be strengthened through investment in training and positive communication.

Obisi (2016) conducted a study to ascertain the empirical validity of the migration to virtual workspace by organizations in Anambra state, South East of Nigeria. Examining the empirical validity of adjustment to virtual workspace by organizations in Anambra state, was the main objective of the research. The study adopted questionnaires as the major source of data. Self-administration of the questionnaires were done to 1200 respondents of organizations in the chosen area, of these 900 responses were retrieved. To eliminate bias and create an equal opportunity for all potential respondents, random sampling method was adopted in the selection process. The 5point Likert scale rating of the responses was made. The statistical package for social sciences (SPSS) was the statistical tool used for data analysis. The result of the study shows that there is a positive domestic balance between the level of internet connectivity, usage and tele-density on the one hand and domestic balancing framework for the operation of virtual arrangement in the country on the other hand. Further findings were that there was a significant role that the nature of interpersonal relationship among employees of business organizations play in the application of virtual work arrangement in the country. Finally, the study concludes that migration to virtual workplace is gaining rapid acceptance in most developed nations like Nigeria as a way of redressing employeesemployer conflict and also is leading to an increased employee performance.

Conill (2013) researched on motivation in virtual project management on the challenges of engaging virtual teams and features of project software in USA. The aim of the study was to examine the dynamics of motivation in the virtual workspace, the contribution it makes to enhance virtual project outcomes and the role that virtual project management software plays in engendering motivation amongst remote teams. Purposive sampling techniques was adopted, this established a good handshake between research questions and the actual sampling. Skype was adopted to conduct interviews in this study to factor in the benefits of face-to-face interaction. Data analysis was done in twofold: firstly, was thematic analysis which is suited for identifying, analyzing, and reporting the patterns or themes that exists within data. Secondly, was the benchmarking technique which allowed a clear understanding of the tools that lead to understanding of outcomes from the design perspective, but also from the functionalities offered to managers and employees.

\section{Methodology}

This study adopted the descriptive survey research design. This design is employed to draw samples from 23 operational banks. The purpose is to collect responses from employees of these banks which will allow for a determination, evaluation, assessment, and examination of the effect of virtual workspace adoption on organization 
performance. Questionnaires were used to collect primary data while secondary data were obtained from documented works such as textbooks, journals, articles, and published data sourced from online sources. The study adopted census method, also known as "complete enumeration" (used when the data sample is small or it reasonable to include the entire population, Kothari (2004)) in which 399 staff across the 23 banks were selected as respondents. The five-point likert scale format was adopted for the questionnaire design. A pre-test was conducted on the questionnaire to test the instrument validity. This was done by a panel of five management experts in the industry who made the necessary correction to ensure that the instrument measure what it was built to measure. The test-retest method with the help of Cronbach Alpha coefficient was used to test reliability. The results showed a high degree of internal consistency with a reliability coefficient of 0.883 . Data collected were presented in frequency tables while the statistical tools used to test the formulated hypotheses was the simple linear regression coefficient.

Table 3.1.1 Questionnaire Distribution and Retrieval

\begin{tabular}{|l|l|l|}
\hline Questionnaire & Number & Percentage (\%) \\
\hline Retrieved and usable & 381 & 95.5 \\
\hline Not Retrieved/Retrieved but not Usable & 18 & 4.5 \\
\hline Total & $\mathbf{3 9 9}$ & $\mathbf{1 0 0}$ \\
\hline
\end{tabular}

Source: Researcher's Computation, 2020

From the table above, three hundred and ninety-nine (399) copies of questionnaire were distributed to top customers of deposit money banks in Nigeria. Out of the 399 copies of the questionnaire, three hundred and eightyone (381) corresponding to $95.5 \%$ copies were filled, retrieved and useful, which were used for analysis while 18 corresponding $4.5 \%$ were among the not retrieved or retrieved data but invalid for the analysis. See chart below.

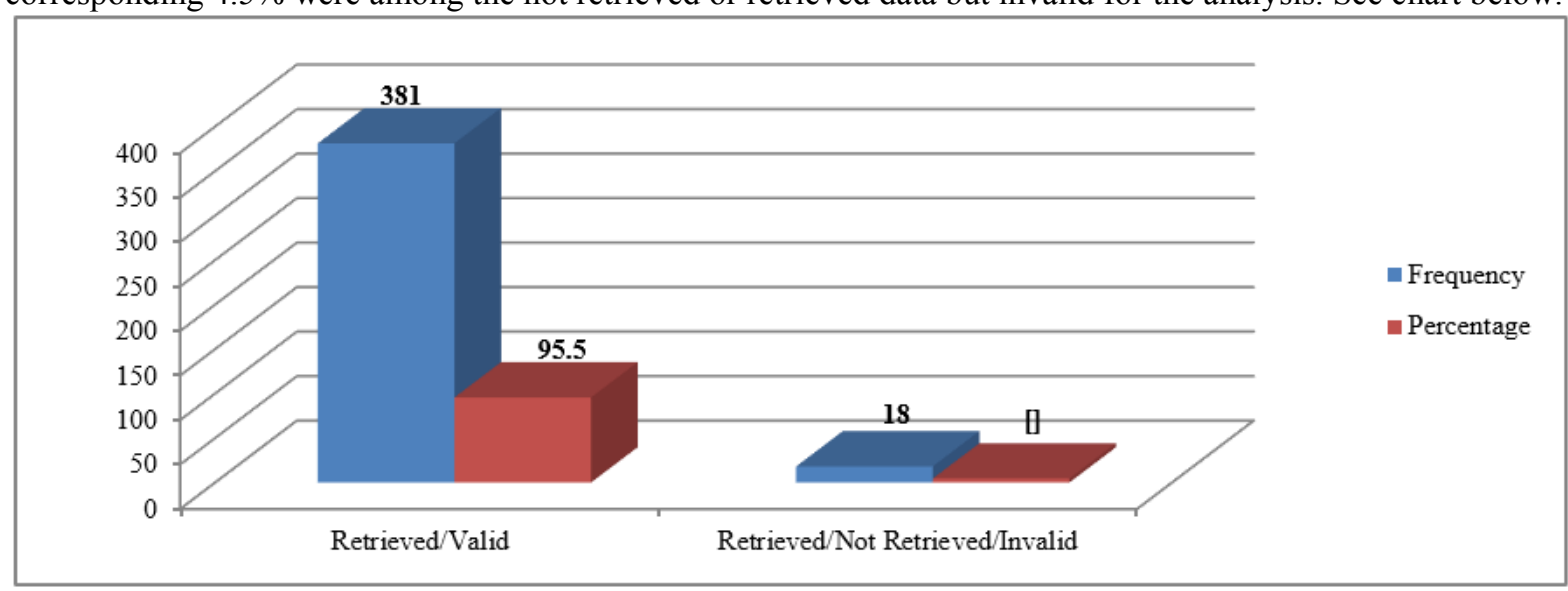

Figure 2: Bar Chart representation of questionnaire responses

Data Presentation and Analyses

Results and Discussion

Decision rules

In testing the hypotheses the following rules are followed strictly to arrive at the final decisions:

- Accept the Null hypotheses (Ho) and reject the Alternate hypotheses (Ha) if the probability value (PV) $>0.05$ and the correlation value $<0.5$.

- $\quad$ Reject the Null hypotheses (Ho) and accept the Alternate hypotheses (Ha) if the probability value (PV) $<0.05$ and the correlation value $>=0.5$.

- The strength of the relationship is decided thus; -0.1 to -0.4 (weak negative relationship), -0.5 to -0.6 (moderate negative relationship), -0.7 to -0.8 (strong negative relationship), -10 (very strong negative relationship) while $\pm 0.0-0.39$ (weak positive relationship), $\pm 0.4-0.59$ (moderate positive relationship), \pm 0.6 - 79 (strong positive relationship), $\pm 0.8-1.00$ (very strong positive relationship).

Test of Hypotheses

Test of Hypothesis One (Ho1):

There is no significant relationship between Virtual workspace adoption and organizational performance of Nigeria banking industry. 
Multiple Regression Analysis for the measures of virtual workspace adoption and organizational performance

Table 4.2.1:Multiple Regression Analysis showing the relationship between intranet facility and organizational performance.

Variables Entered/Removed ${ }^{\text {a }}$

\begin{tabular}{|l|l|l|l|}
\hline Model & Variables Entered & Variables Removed & Method \\
\hline 1 & $\begin{array}{l}\text { Intranet facility, } \\
\text { Extranet facility }\end{array}$ & & Enter \\
\hline
\end{tabular}

a. Dependent Variable: organizational performance

b. All requested variables entered.

\begin{tabular}{|l|r|r|r|r|}
\hline Model & \multicolumn{1}{|c|}{$\mathrm{R}$} & R Square & \multicolumn{1}{|c|}{$\begin{array}{c}\text { Adjusted R } \\
\text { Square }\end{array}$} & Std. Error of the Estimate \\
\hline 1 & $.883^{\mathrm{a}}$ & .788 & .866 & .23923 \\
\hline
\end{tabular}

a. Predictors: (Constant), intranet facility and extranet facility

ANOVA $^{\mathrm{a}}$

\begin{tabular}{|ll|r|r|r|r|r|}
\hline Model & & Sum of Squares & \multicolumn{1}{|c|}{ Df } & Mean Square & \multicolumn{1}{c|}{ F } & Sig. \\
\hline \multirow{2}{*}{1} & Regression & 616.345 & 2 & 205.448 & 3589.843 & $.000^{\mathrm{b}}$ \\
& Residual & 21.576 & 377 & .057 & & \\
& Total & 637.921 & 381 & & & \\
\hline
\end{tabular}

a. Dependent Variable: organizational performance

b. Predictors: (Constant), intranet facility

Coefficients $^{\mathrm{a}}$

\begin{tabular}{|c|c|c|c|c|c|}
\hline \multirow[t]{2}{*}{ Model } & \multicolumn{2}{|c|}{ Unstandardized Coefficients } & \multirow{2}{*}{$\begin{array}{c}\text { Standardized } \\
\text { Coefficients }\end{array}$} & \multirow[t]{2}{*}{$\mathrm{T}$} & \multirow[t]{2}{*}{ Sig. } \\
\hline & $\mathrm{B}$ & Std. Error & & & \\
\hline (Constant) & .009 & .027 & & 324 & $\begin{array}{r}.0 .001 \\
.000 \\
.000\end{array}$ \\
\hline Intranet facility & .223 & .040 & .283 & 584 & .000 \\
\hline
\end{tabular}

a. Dependent Variable: organizational performance

\section{REGRESSION EQUATION MODEL:}

\section{$\mathbf{Y}=\boldsymbol{\alpha}+\boldsymbol{\beta}$}

Decision

The result of the multiple regression of the above variables is $R=0.883$ which is equal to $88 \%$. The " $R$ " value indicates a high degree of correlation while " $\mathrm{R}^{2}$ " shows how much variation in intranet facility can be explained by the measure of the independent variables. This means that $88 \%$ variation in intranet facility can be explained by factors within the model used for the study and the remaining $12 \%$ can only be explained by other external quantitative and qualitative factors of the model used for the study. It also shows a strong positive and positive correlation.

The beta standard coefficient value (i.e. 0.283 ) shows the strength or contributions of dimensions of the predictor variable. Therefore, the null hypothesis of no significant effect is rejected. Thus, intranet facility has a significant relationship with organizational performance.

However, $\mathrm{R}^{2}=0.788$ and $\mathrm{Sig}<0.05$. Therefore $\mathbf{H O}_{1}$, are rejected and alternative hypotheses accepted. 
Table 4.2.2:Multiple Regression Analysis showing the relationship between extranet facility and organizational performance.

Model Summary

\begin{tabular}{|l|r|r|r|rr|}
\hline Model & \multicolumn{1}{|c|}{$\mathrm{R}$} & \multicolumn{1}{|c|}{ R Square } & \multicolumn{1}{|c|}{$\begin{array}{c}\text { Adjusted R } \\
\text { Square }\end{array}$} & Std. Error of the Estimate \\
\hline 1 & $.823^{\mathrm{a}}$ & .677 & .878 & .45179 \\
\hline
\end{tabular}

a. Predictors: (Constant), intranet facility and extranet facility

ANOVA ${ }^{\mathrm{a}}$

\begin{tabular}{|rl|r|r|r|r|r|}
\hline Model & & Sum of Squares & \multicolumn{1}{|c|}{ Df } & Mean Square & \multicolumn{1}{c|}{ F } & Sig. \\
\hline \multirow{3}{*}{1} & Regression & 559.746 & 3 & 186.582 & 914.086 & $.000^{\mathrm{b}}$ \\
& Residual & 76.953 & 378 & .204 & & \\
& Total & 636.698 & 381 & & & \\
\hline
\end{tabular}

a. Dependent Variable: organizational performance

b. Predictors: (Constant), extranet facility

Coefficients $^{\mathrm{a}}$

\begin{tabular}{|c|c|c|c|c|c|}
\hline \multirow[t]{2}{*}{ Model } & \multicolumn{2}{|c|}{ Unstandardized Coefficients } & \multirow{2}{*}{$\begin{array}{c}\text { Standardized } \\
\text { Coefficients }\end{array}$} & \multirow[t]{2}{*}{$\mathrm{T}$} & \multirow[t]{2}{*}{ Sig. } \\
\hline & B & Std. Error & & & \\
\hline (Constant) & .121 & .051 & & 2.381 & $\begin{array}{r}.0 .001 \\
.000 \\
.000\end{array}$ \\
\hline Extranet facility & .525 & .075 & .152 & 936 & .000 \\
\hline
\end{tabular}

a. Dependent Variable: organizational performance

\section{REGRESSION EQUATION MODEL:}

$\mathbf{Y}=\boldsymbol{\alpha}+\boldsymbol{\beta}$

Decision

The result of the multiple regression of the above variables is $\mathrm{R}=0.823$ which is equal to $82 \%$. The " $\mathrm{R}$ " value indicates a high degree of correlation while " $\mathrm{R}$ " " shows how much variation in extranet facility can be explained by the measure of the independent variables. This means that $68 \%$ variation in extranet facility can be explained by factors within the model used for the study and the remaining $32 \%$ can only be explained by other external quantitative and qualitative factors of the model used for the study. It also shows a strong positive and positive correlation.

The beta standard coefficient value (i.e. 0.152) shows the strength or contributions of dimensions of the predictor variable. Therefore, the null hypothesis of no significant effect is rejected. Thus, extranet facility has a significant relationship with organizational performance.

However, $\mathrm{R}^{2}=0.677$ and $\mathrm{Sig}<0.05$. Therefore $\mathbf{H O}_{2}$, are rejected and alternative hypotheses accepted.

\section{Discussion of Findings / Interpretations}

The result of $\mathrm{Ho}_{1}$ indicated that positive relationship exist between intranet facility and organizational performance of $* 0.883$. This means that $79 \%$ variation in intranet facility can be explained by factors within the model used for the study and the remaining $21 \%$ can only be explained by other external factors of the model used for the study. This thus shows a strong positive and positive correlation.

Also, the result of $\mathrm{Ho}_{2}$ indicated that positive relationship exist among extranet facility and organizational performance with a regression of $* 823$ which is equal to $79 \%$. The " $R$ " value indicates a high degree of correlation while " $\mathrm{R}$ " shows how much variation in extranet facility can be explained by the measure of the independent variables. This means that $68 \%$ variation in extranet facility can be explained by factors within the model while the remaining $32 \%$ can only be explained by other external factors of the model used for the study which also show a strong positive relationship.

Furthermore, it was revealed that the findings of the study are in affirmation with theoretical and empirical studies of several other researchers in similar subject matter

\section{Conclusion}

The findings of this research will have significant managerial implications for the banking industry in Nigeria in terms of building a virtual workspace through an effective intranet and extranet system, a common online 
supportive collaboration environment, virtual training system and an effective virtual relationship between managers and employees which allows both management and employees to be effective, productive, loyal and developed.

The study concludes that the there is a positive relationship between intranet, extranet facility and organizational performance.

\section{Recommendations}

The following recommendations were made based on the findings:

i. The managers or head of the banks should endeavor to equip and train staff in the utilization of virtual workspace.

ii. Bank technical team and system developers should ensure that sites and apps are designed with optimum simplicity to ensure ease of use and reduce TAT (turnaround time).

iii. Banks should design their electronic space in such a way that reversals and erroneous transactions can be treated online without the customer having to come to the bank, as this will build trust.

\section{Contribution to Knowledge}

From the review of related literature very few studies contrasted Virtual Workspace Adoption and organizational performance; hence the study provided a new framework that would serve as a guide to marketing/management practitioners and students in the same field of study. In addition, other scholars should carry out a study in other region and variables. This also serves as the dissertation's contribution to knowledge.

\section{Future Research}

The study only adopted multiple regressions as the analytical tool with the aid of SPSS. Thus, other scholars should endeavor to adopt statistical tools like Product Pearson correlation coefficient, kendalls, Chi-square with the aid of E-views and other related statistical packages to check if the correlation will vary.

\section{References}

Axero, D. (2018) Using internet facilities for grounding and awareness in collaborative tasks. Professional Communication, IEEE Transactions on. 45 (4), 219-230.

Bavec, C. (2002). An assessment of the organization virtuality with three different reference models. Informatics. 26 (4) $221-347$

Bell, B.S. \& Kozlowski, W. J.S. (2002). A typology of virtual teams, implications for effective leadership. Group and Organization Management, 27(1), 14-49.

Berry, R. G. (2011). Enhancing effectiveness on virtual teams: Understanding why traditional team skills are in sufficient. Journal of Business Communication, 2(48), 186-206.

Boundless, L. L. (2017). Cultivating service brand equity. Journal of Academy and Marketing Science 28, 128137.

Business dictionary (2017). Business dictionary. com ( $\left.7^{\text {th }} \mathrm{ed}\right)$.

Cherbakov, L. (2009).Virtual spaces: Enabling immersive collaborative enterprise, Part 1: Introduction to the opportunities and technologies. International Business Journal, 30(6), 12-21.

Conill, R.F. (2013). Motivation in virtual project management on the challenges of engaging virtual teams and the features of project software.www.hhk.kau.se.

Daniel, J. L. (2015). The effect of employee attitude on organization's performance. Journal of Management Development, 29 (5), 442-456.

Dreck, F. (2016). Managing a virtual workplace in the banking industry. The Academy of Management Executive, 14 (3) 81-90.

Don Havstrand, G.O. (2009). Capacity building: A tool for increase productivity in Nigeria public sector organization. Journal of Accounting Research, 36(21), 22-44.

Duarte, D. \& Snyder, N. (2006). Mastering virtual teams: Strategies, tools, and techniques that succeed. John Wiley \& Sons, Inc.

Dutta \& Segev's theory (2001). Theory of cyber transformation. American journal of technology, 63, $597-606$.

Fajana, K., Owoyemi, E. \& Gbajumo, S. (2015). Coworker relationships and informal communication in high intensity telecommuting. Journal of Applied Communication Research, 39(4), 144163.

Hanth, S., \& Tracy, M. (2017). Reverse mentoring a social exchange tool for keeping the boomers engaged and millennial committed. Human Resource Development Review, 11(1), 55-76.

Holt, Z. (2016). Benefits of extranet. Made E-Z Products Inc.

Howard, M. \& Upton, H. (2001). An introduction to business finance. McGraw Hill.

Ihenyen, I. (2015). E-commerce evolution in Nigeria: Opportunities and threats. Nigerian Law Today, 8 (2), 11.

Kothari, A. (2004). Research methodology. Polity. 
Lee, J. (2013). The world is flat: A brief history of the twenty-first century. Farra, Straus and Giroux .

Loughran, J. (2005). Working together virtually: The care and feeding of global virtual teams. http://www.thoughtlink.com

Mitchell, R.N. (2015). The correlation between virtual communication and employee engagement. http://scholarworks.waldenu.edu/dissertations.

Obisi, C. (2016). The empirical validity of the adjustment to virtual work arrangement by business organizations in Anambra state, Nigeria. International Journal of Scientific Research in Education, 9(3), 173-181.

Pen, A. (2019). Explaining the difference of work attitudes between public and nonprofit managers: The views of rule constraints and motivation styles. The American Review of Public Administration, 42, 437-460.

Peters, L.M. \& Manz, C.C. (2017). Identifying antecedents of virtual team collaboration. Team Performance Management, 13, 117-129.

Powell, A., Piccoli, G. \& Ives, B. (2014). Virtual teams: team control structure, work processes, and team effectiveness. Information Technology and People, 17 (4), 359379.

Shereen, M. (2018). Business uses and benefits of intranets and extranets. Veriday.com/blog.

Steven, D. (2015). Brand equity brand preference and purchase intent. Journal of Advertising, 24 (32), 25-40.

Wang, D., Su, Z. \& Yang, D. (2011). Organizational culture and knowledge creation capability. Journal of Knowledge Management, 15(3), 363-373

Wendy, S. (2019). Managing virtual teams. Asian development bank (ADB). Knowledge Solution Article Manila, $4(2), 1-6$.

Yaha, A. (2018). Avoid waiting time at the banking hall: An integrative framework for understanding customer satisfaction. International Journal of e-Collaboration, 9(2), 1-33.

Yang, F. (2015). Information and communication influencing the rise of entrepreneurship in Nigeria. Journal of Information Technology, 10 (7), 71 -79. 